\title{
Tumor Results Assessment Test
}

National Cancer Institute

\section{Source}

National Cancer Institute. Tumor Results Assessment Test. NCI Thesaurus. Code

C117426.

A character or string that represents the long name of the tumor assessment. 